\title{
Expression of NEP1 by Fusarium oxysporum f. sp. erythroxyli After Gene Replacement and Overexpression Using Polyethylene Glycol-Mediated Transformation
}

\author{
B. A. Bailey, Patricia C. Apel-Birkhold, and Douglas G. Luster
}

First and second authors: USDA-ARS, Alternate Crops and Systems Laboratory, Bldg. 001, Rm. 342, BARC-West, Beltsville, MD 20705; and third author: USDA-ARS, Foreign Diseases-Weed Science Research Unit, Fort Detrick, MD 21702.

Current address of P. C. Apel-Birkhold: Dow AgroSciences LLC, 9330 Zionsville Road, Building 306, 1D, Indianapolis, IN 46268.

Accepted for publication 28 March 2002.

\begin{abstract}
Bailey, B. A., Apel-Birkhold, P. C., and Luster, D. G. 2002. Expression of NEPI by Fusarium oxysporum f. sp. erythroxyli after gene replacement and overexpression using polyethylene glycol-mediated transformation. Phytopathology 92:833-841.

The necrosis inducing extracellular protein Nep1 is produced by Fusarium oxysporum f. sp. erythroxyli in liquid culture. NEP1, the Nep1 protein structural gene, was disrupted in F. oxysporum f. sp. erythroxyli isolate EN-4 by gene replacement using polyethylene glycol (PEG)mediated transformation. NEP1 disruption was verified by polymerase chain reaction (PCR), Southern blot, and northern blot analysis. NEP1disrupted transformants failed to produce Nep1 in liquid culture. NEP1 disruption did not affect the pathogenicity of isolate EN-4 toward Erythroxylum coca. Transformation of isolate EN-4 with construct pPB-

sulted in increased production of Nep1 in potato dextrose broth plus $1 \%$ casamino acids or Czapek-Dox broth plus $1 \%$ casamino acids but not in potato dextrose broth alone. Transformation of EN-4 with construct pPBFO11-45 was verified by PCR and Southern blot analysis. Overexpression of NEP1 was confirmed by northern blot and Tricine-sodium dodecyl sulfate-polyacrylamide gel electrophoresis analysis. NEP1-overexpressing transformant 15 produced 64 to 128 times as much Nep1 as EN-4 wild type when grown in shake cultures. Transformants overexpressing Nep1 in liquid culture were no more or less pathogenic toward E. coca than wild-type isolates. Nep1 was not detected in E. coca seedlings infected with NEP1-overexpressing transformants or with EN-4 wild type. In large-scale fermentations of $N E P 1$-overexpressing transformant 15 , the amount of secreted protein including Nep1 was 15.1 times that of the wild-type EN-4, providing a ready source of Nep1 for future study.
\end{abstract} FO11-45 carrying NEP1 between the $\operatorname{trpC}$ promoter and terminator re-
Fusarium oxysporum, a common soil inhabitant, has the ability to grow saprophytically, and can be a plant pathogen causing vascular wilt of many plant species (5). Nep1 is a $24-\mathrm{kDa}$ necrosis-inducing extracellular protein produced by $F$. oxysporum $\mathrm{f}$. sp. erythroxyli in liquid culture (1). The growth medium composition greatly influences the production of Nep1 by F. oxysporum, which under certain conditions can be the major extracellular protein produced (4). Nep1 is phytotoxic to many different dicot plant species but does not significantly affect monocots (1). The range of dicots sensitive to Nep1 includes plant families as distantly related as Erythroxylaceae, Solanaceae, Aceraceae, Rosaceae, and Brassicaceae. Concentrations as low as $0.5 \mu \mathrm{g} / \mathrm{ml}$ cause necrosis of dicot leaves $(1,14)$, often within $4 \mathrm{~h}$ of treatment. In addition to necrosis, tobacco cellular responses to Nep1 treatment include ethylene production, active oxygen production, altered cell respiration, $\mathrm{K}^{+}$and $\mathrm{H}^{+}$channel fluxes, and altered gene expression (14).

Nep1 causes necrosis when applied as a foliar spray to dicot plant species including many weed species (13). Nep1 penetrates the leaf through the stomata and rapidly kills the surrounding cells, acting much like a contact herbicide (3). Nep1 can act in combination with the bioherbicidal fungus Pleospora papaveracea to enhance control of opium poppy (2). It has also been demonstrated that Nep1 activity is stable when co-applied with the herbi-

Corresponding author: B. A. Bailey; E-mail address: baileyb@ba.ars.usda.gov

Publication no. P-2002-0531-01R

This article is in the public domain and not copyrightable. It may be freely reprinted with customary crediting of the source. The American Phytopathological Society, 2002. cides 2,4-D and glyphosate, resulting in accelerated development of necrosis in spotted knapweed (Centaurea maculosa) (3).

The gene for Nep1 has been cloned and partially characterized (22). NEPl is made up of two exons interrupted by a 58-nucleotide intron. The Nep1 protein is 253 amino acids long, including a 31-amino-acid signal peptide that is removed during protein processing. The protein is produced by many different $F$. oxysporum isolates (4). Isolates of $F$. acuminatum and $F$. avenaceum produce antigenically related proteins of similar size and activity (4). Recent comparisons to sequence databases have identified related gene products produced by Pythium aphanidermatum, (AAD53944) Streptomyces coelicolor (CAB92890), several Phytophthora spp. (AAK01636, AAK19753, and AAK25829), Bacillus halodurans (BAB04114), and Vibrio spp. (CAC40975), suggesting Nep1-related proteins are widely produced by taxonomically divergent microorganisms. What purpose Nep1 serves in the biology of $F$. oxysporum or any other organism is unknown despite its common occurrence.

The objective of this research was to use polyethylene glycol (PEG)-mediated transformation techniques to alter production of Nep1 in the F. oxysporum f. sp. erythroxyli wild-type strain resulting in gene disruption or overexpression. The goals of this work were to determine the influence of Nep1 on disease development and to enhance production capabilities of Nep1, allowing more intensive studies of the mode of action of Nep1 and its potential use as a natural herbicide for the control of broadleaf weeds.

\section{MATERIALS AND METHODS}

Production and bioassay of culture filtrates. The coca pathogen $F$. oxysporum f. sp. erythroxyli isolate EN-4 (23) was main- 
tained on plates of Komada's medium (17) in a $23^{\circ} \mathrm{C}$ incubator for daily use. EN-4 wild type and selected transformed EN-4 isolates were preserved as toothpick stock cultures (23). Liquid shake cultures $(120 \mathrm{rpm})$ of the fungal isolates were typically grown in Czapek-Dox (CDX) broth plus $1 \%$ casamino acids (CAA). Where mentioned, isolates were grown in potato dextrose broth (PDB) plus or minus $1 \%$ CAA. Cultures were grown for up to 7 days at $25^{\circ} \mathrm{C}$. Samples for extracellular protein analysis were produced by filtering cultures through Whatman No. 1 filter paper. The filtrates were then centrifuged $(5 \mathrm{~min}$ at $15,800 \times g)$ to remove microconidia and stored at $-20^{\circ} \mathrm{C}$ until used.

Leaves of Erythroxylum coca var. coca were collected from greenhouse-grown plants (1). A 5- $\mu$ l drop of fungal culture filtrate was applied to the freshly cut petiole. After the drop was absorbed, the leaves were placed in a 58-ml jar with petioles in assay buffer (10 mM 2-[ $N$-morpholino]ethanesulfonic acid [MES], $250 \mathrm{mM}$ sorbitol, $\mathrm{pH}$ 6.0). The jars were sealed with rubber stoppers containing ports capped with rubber septa. Ethylene measurements were taken after $24 \mathrm{~h}$ (1).

Large-scale fermentation. Large-scale fermentation was carried out in 10-liter carboys maintained at room temperature (approximately $23^{\circ} \mathrm{C}$ ) for up to 10 days. Carboys were filled with 6 liters of CDX plus $1 \% \mathrm{CAA}$ and autoclaved for $1 \mathrm{~h}$. Carboys were inoculated with $20 \mathrm{ml}$ of a 2-day liquid shake culture of EN-4 wild type or NEP1-overexpressing isolate 15. Large-scale fermentation was carried out with each isolate twice. The carboys were sparged with filtered air (approximately 100 liters/h). Twenty-milliliter samples were collected daily, and the numbers of microconidia produced were determined by standard methods using a hemacytometer. Two 1-ml aliquots of daily samples were centrifuged $(15,800 \times g$ for $5 \mathrm{~min})$ to remove the fungal biomass, and the supernatant was stored at $-20^{\circ} \mathrm{C}$ for future protein analysis. After 10 days, the carboy contents were filtered through cheesecloth to collect the mycelial biomass. The biomass was oven-dried for $48 \mathrm{~h}$ at $50^{\circ} \mathrm{C}$ and weighed.

Pathogenicity testing. The pathogenicity of EN-4 wild type and selected EN-4 transformants with altered NEPI expression was determined by a root-dip assay (23). Each isolate was evaluated for pathogenicity in two separate experiments. Autoclaved inoculum of both EN-4 wild type and several EN-4 transformants were included as controls. Rating was based on the number of defoliated seedlings per pot, with each pot having a maximum score of 4. Stem segments were collected from defoliated seedlings and plated on Komada's medium (23). The plates were incubated at

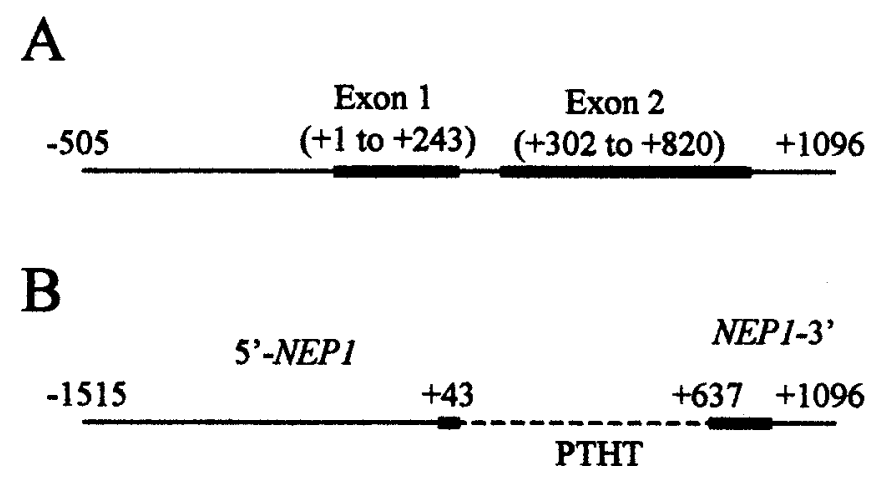

Fig. 1. Plasmid construct pPB-FO11-45 for overexpression of NEP1 carried A, the NEP1 gene between two XhoI sites $(-505$ to +1096$)$ cloned into the ClaI (5') site after the $\operatorname{trpC}$ promoter and BamHI $\left(3^{\prime}\right)$ site before the trpC terminator of pTHT/Bluescript $\mathrm{SK}^{+}$. Plasmid construct pPB-FO16-1 for disruption of $N E P 1$ carried $\mathbf{B}$, the $5^{\prime}$ end $\left(5^{\prime}-N E P 1\right)$ of $N E P 1$ between the HindIII site $(-1515)$ and a BstXI site $(+43)$ inserted into a SalI site $5^{\prime}$ of the trpC promoter of PTHT/bluescript $\mathrm{SK}^{+}$plus the $3^{\prime}$ end $\left(N E P 1-3^{\prime}\right)$ of $N E P 1$ between a PstI site $(+637)$ and XhoI site (+1096) inserted $3^{\prime}$ of the $\operatorname{trpC}$ terminator at a NotI site. Solid lines represent NEP1 sequence, with thick solid lines representing translated regions. $23^{\circ} \mathrm{C}$ for 3 days, after which fungal colonies emerging from the stem cut ends were transferred to new plates and maintained for further study.

Fungal transformation. Transformation of EN-4 was carried out using a modification of the methods of Inoue et al. (12). Ten micrograms of each plasmid DNA was added to $100 \mu \mathrm{l}(2 \times$ $10^{7}$ cells) of protoplasts in a 14-ml Falcon tube (BD Biosciences, Franklin Lakes, NJ) and kept on ice for $20 \mathrm{~min}$. One milliliter of PEG buffer (60\% PEG 4000, $10 \mathrm{mM}$ Tris-HCl [pH 7.5], and $10 \mathrm{mM} \mathrm{CaCl}_{2}$ ) was gently added and the mixture was incubated at $20^{\circ} \mathrm{C}$ for $30 \mathrm{~min}$. The mixture was centrifuged $(700 \times g)$ for $5 \mathrm{~min}$ to recover the protoplasts, which were then resuspended with $600 \mu \mathrm{l}$ of STC buffer (1.2 M sorbitol, $10 \mathrm{mM}$ Tris- $\mathrm{HCl}$ [pH 7.5], and 10 $\mathrm{mM} \mathrm{CaCl} 2$. The protoplast suspension $(200 \mu \mathrm{l}$ per plate) was spread on YPSA $(0.1 \%$ yeast extract, $0.1 \%$ tryptone, $1 \mathrm{M}$ sucrose, and $2 \%$ agar) plates. The plates were incubated at $25^{\circ} \mathrm{C}$ overnight and overlaid with $20 \mathrm{ml}$ of potato dextrose agar (PDA) containing $100 \mu \mathrm{g}$ of hygromycin B per ml. After an additional $24 \mathrm{~h}$ of incubation, each plate was again overlaid with $10 \mathrm{ml}$ of PDA containing $100 \mu \mathrm{g}$ hygromycin B per ml. After 3 to 7 days at $25^{\circ} \mathrm{C}$, the emerging colonies were transferred to PDA plates containing $100 \mu \mathrm{g}$ hygromycin B per ml. Subsequently, the putative transformants were single spore isolated by dilution plating and the pure strains were stored at $4^{\circ} \mathrm{C}$ on dry, colonized toothpicks as previously described (23).

Plasmid construction. pTHT/Bluescript $\mathrm{SK}^{+}(5,018 \mathrm{bp})$ was constructed by inserting the SalI-XbaI fragment from pHRC (16) carrying the hygromycin gene $h p h$ flanked by the $\operatorname{trp} C$ promoter and $\operatorname{trpC}$ terminator (6) into the $\mathrm{pBS} \mathrm{SK}^{+}$(Stratagene, La Jolla, CA) multiple cloning site. Plasmid construct pPB-FO11-45 (5,578 bp) for overexpression of NEP1 (23) carried the NEP1 gene between two XhoI sites $(-505$ to +1096$)$ cloned into the ClaI $\left(5^{\prime}\right)$ site after the $\operatorname{trpC}$ promoter and $\mathrm{BamHI}\left(3^{\prime}\right)$ site before the $\operatorname{trpC}$ terminator of pTHT/Bluescript $\mathrm{SK}^{+}$(Fig. 1A). Plasmid pPB-FO11-45 had $N E P l$ in place of $h p h$ and was cotransformed with $\mathrm{pTHT} / \mathrm{Blue}$ script $\mathrm{SK}^{+}$using hygromycin resistance as a selectable marker. pPB-FO16-1 (7,039 bp) for disruption of NEP1 (23) carried the 5' end of NEPI between the HindIII site $(-1515)$ and a BstXI site $(+43)$ inserted into a SalI site $5^{\prime}$ of the $\operatorname{trpC}$ promoter of PTHT/ Bluescript $\mathrm{SK}^{+}$plus the $3^{\prime}$ end of NEPl between a PstI site $(+637)$

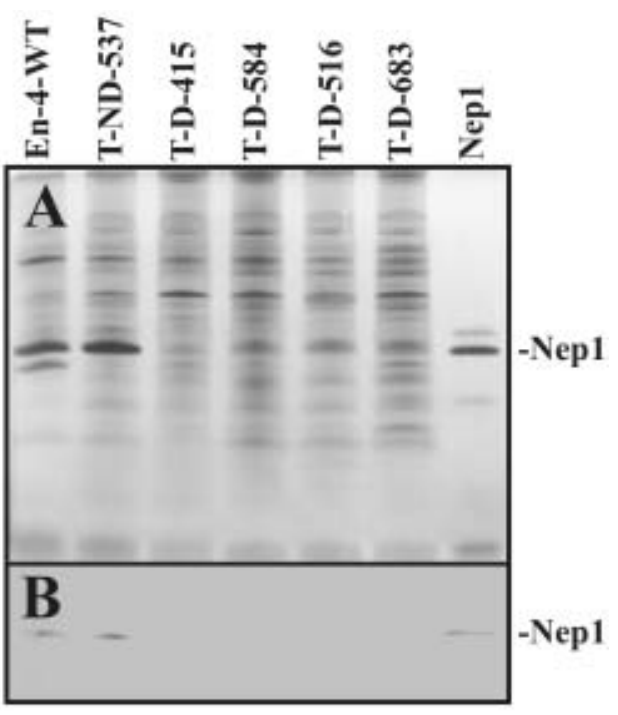

Fig. 2. Culture filtrate protein profiles produced by putative NEP1-disrupted isolates (T-D-415, T-D-584, T-D-516, and T-D-683) produced by transformation-mediated gene replacement using plasmid pPB-FO16-1. Isolates producing wild-type levels of Nep1 (En-4 wild type and T-ND-537) are presented for comparisons. The proteins in $5 \mu \mathrm{l}$ of culture filtrate were separated by sodium dodecyl sulfate-polyacrylamide gel electrophoresis and either $\mathbf{A}$, silver stained or $\mathbf{B}$, western blotted. 
and XhoI site $(+1096)$ inserted $3^{\prime}$ of the $\operatorname{trpC}$ terminator at a NotI site (Fig. 1B).

Protein profiles (silver stain and western blot). Protein profiles of culture filtrates were determined for each isolate by Tricine-sodium dodecyl sulfate-polyacrylamide gel electrophoresis (SDS-PAGE) using the Tris/Tricine system (26) with a gel system (Mini-PROTEAN II; Bio-Rad, Hercules, CA). As standard protocol, equal volumes of protein samples were loaded without addition of 2-mercaptoethanol (1). The gels were either silverstained (30) or western blotted and immuno-stained using antiserum to denatured Nep1 (4).

DNA isolation for polymerase chain reaction. Each isolate was grown at $25^{\circ} \mathrm{C}$ on a rotary shaker $(200 \mathrm{rpm})$ for 3 days in $10 \mathrm{ml}$ of CDX plus $1 \%$ CAA in a $50-\mathrm{ml}$ Falcon tube. The 3 day culture was filtered onto Whatman No. 2 paper, rinsed with distilled water, and the fungal biomass was transferred to a $15-\mathrm{ml}$ round bottom tube. The biomass was snap frozen in liquid $\mathrm{N}_{2}$ and stored at $-80^{\circ} \mathrm{C}$. The biomass was lyophilized and ground with a glass rod under liquid $\mathrm{N}_{2}$. The powder was transferred to a $1.5-\mathrm{ml}$ microfuge tube and mixed with $600 \mu \mathrm{l}$ of extraction buffer $(2 \%$ SDS, $100 \mathrm{mM}$ Tris- $\mathrm{HCl}[\mathrm{pH} 8.0], 100 \mathrm{mM} \mathrm{NaCl}$, and $10 \mathrm{mM}$ EDTA) and $10 \mu \mathrm{l}$ of $10 \mathrm{mg} / \mathrm{ml}$ RNase A prior to incubating at $65^{\circ} \mathrm{C}$ for $30 \mathrm{~min}$. The biomass extract $(600 \mu \mathrm{l})$ was mixed with $600 \mu \mathrm{l}$ of phenol/chloroform/isoamyl alcohol in a 25:24:1 ratio. The phenol had been equilibrated with Tris- $\mathrm{HCl}, \mathrm{pH} 7$. The mixture was centrifuged for $30 \mathrm{~min}(15,800 \times g)$ and the aqueous phase was transferred to a clean tube. The aqueous phase was extracted with chloroform $(600 \mu \mathrm{l})$, centrifuged for $10 \min (15,800 \times$ $g$ ), and transferred to a clean tube. Isopropanol ( 0.54 volume) was mixed with the aqueous phase and the tube was placed at $-20^{\circ} \mathrm{C}$ for $30 \mathrm{~min}$. The sample was centrifuged for $20 \mathrm{~min}(15,800 \times \mathrm{g})$ to pellet nucleic acids and the supernatant was discarded and the pellet drained. The pellet was suspended in 50 to $100 \mu \mathrm{l}$ of distilled $\mathrm{H}_{2} \mathrm{O}$ by placing tubes at $65^{\circ} \mathrm{C}$. The DNA was stored in a $-20^{\circ} \mathrm{C}$ freezer until used for polymerase chain reaction (PCR) amplification.

PCR conditions. The PCR mixes contained approximately $2.5 \mu \mathrm{g}$ of DNA, $1 \mu \mathrm{M}$ for each of two primers, $0.1 \mathrm{M}$ dithiothreitol, $3 \mathrm{mM} \mathrm{MgCl} 2,100 \mathrm{mM}$ dNTPs, 2 units of Taq DNA polymerase, and the supplied buffer as recommended by the manufacturer (Promega, Madison, WI). Primers p22 (5'-GTTAAGGCGCCAT-

\section{Transformants}

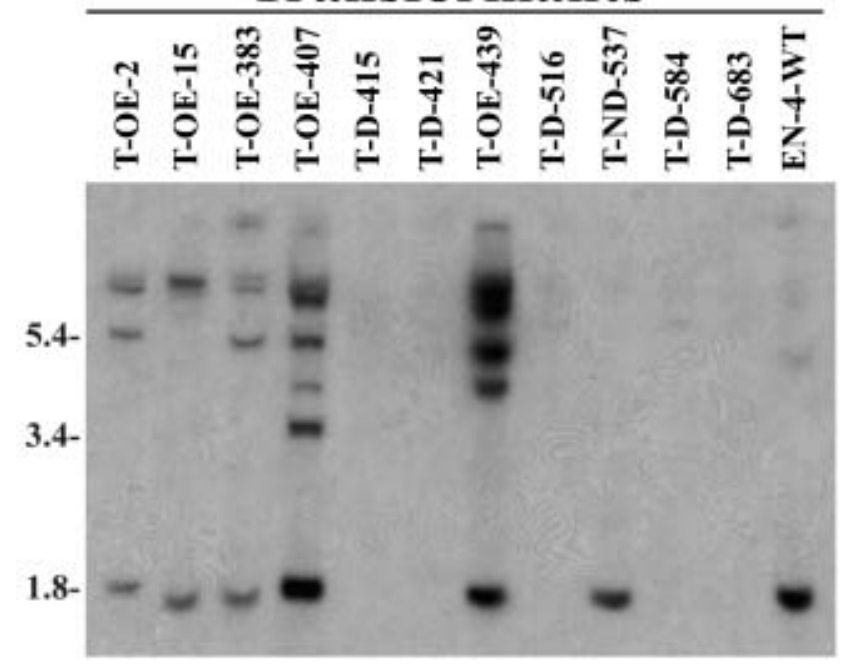

Fig. 3. Southern analysis of SmaI-digested DNA from EN-4 and T-ND-537 producing wild-type levels of Nep1 (WT), putative NEP1-overexpressing isolates T-OE-2, T-OE-15, T-OE-383, T-OE-407, and T-OE-439 (OE), and putative NEP1-disrupted isolates T-D-415, T-D-421, T-D-516, T-D-584, and T-D-683 (D). The digested DNA was separated on agarose gels, blotted, and hybridized to a 381-bp NEP1 probe.
GCATCCTCAGACCATCTT-3') and p23 (5'-ACGCGGATCCTTCAGGACCAGGCCTTGTTGA-3'), both residing within NEP1, were used for PCR amplification to verify NEP1 disruption in transformation experiments, producing a 841-bp band when pFO11-45 was used as DNA template and failing to produce the 841-bp band when NEP1 was disrupted. Primers p39 (5'-CAAGCAAGGTAAGTGAACGAC-3'), located in the $\operatorname{trp} C$ promoter, and p29 (5'-CGTGGAGATTGTTGAGGG-3'), located $3^{\prime}$ to the transcription start site of $N E P 1$, were used to verify transformation in overexpression experiments producing a 692-bp band when pFO11-45 was used as DNA template. The reaction mixture was denatured for $5 \mathrm{~min}$ at $94^{\circ} \mathrm{C}$ prior to the addition of Taq DNA polymerase. The DNA was PCR amplified for 45 cycles of $1 \mathrm{~min}$ at $94^{\circ} \mathrm{C}, 1 \mathrm{~min}$ at $50^{\circ} \mathrm{C}$, and $2 \mathrm{~min}$ at $72^{\circ} \mathrm{C}$. The final extension was for $10 \mathrm{~min}$ at $72^{\circ} \mathrm{C}$ after which the reactions were held at $4^{\circ} \mathrm{C}$. The amplified DNA was separated by electrophoresis on a $1 \%$ agarose gel with Tris-borate-EDTA buffer $(1 \times)$. Ethidium bromide was included in the gel to visualize the DNA that was photographed by a camera with 665 positive/negative black and white film (MP4 Land Camera; Polaroid Corp., Cambridge, MA).

DNA and RNA isolation for Southern and northern blot analysis. Fungal isolates were grown in $100 \mathrm{ml}$ of CDX plus $1 \%$ $\mathrm{CAA}$ at $25^{\circ} \mathrm{C}$ for 3 days, and the biomass was harvested by filtration onto Whatman No. 2 paper and washed twice with deionized water. The washed biomass was transferred to a $50-\mathrm{ml}$ conical tube quickly frozen in liquid nitrogen.

DNA was isolated from lyophilized biomass according to the methods of Yoder (31). Twenty micrograms of genomic DNA was digested in a 100- $\mu$ l reaction using SmaI (Roche, Indianapolis, IN) with its recommended buffer and reaction conditions. Digestions were allowed to proceed for approximately $2 \mathrm{~h}$, with a second addition of restriction enzyme after $1 \mathrm{~h}$ of incubation. The digestion was stopped by the addition of $2 \mu \mathrm{l}$ of $0.5 \mathrm{M}$ EDTA, and precipitated by the addition of $30 \mu \mathrm{l}$ of $10 \mathrm{M}$ ammonium acetate and $264 \mu \mathrm{l}$ of $100 \%$ ethanol, and held overnight at $-20^{\circ} \mathrm{C}$. After centrifugation and brief drying, the pellet was suspended in $30 \mu \mathrm{l}$ of Tris-EDTA. The digested DNA was separated by electrophoreses

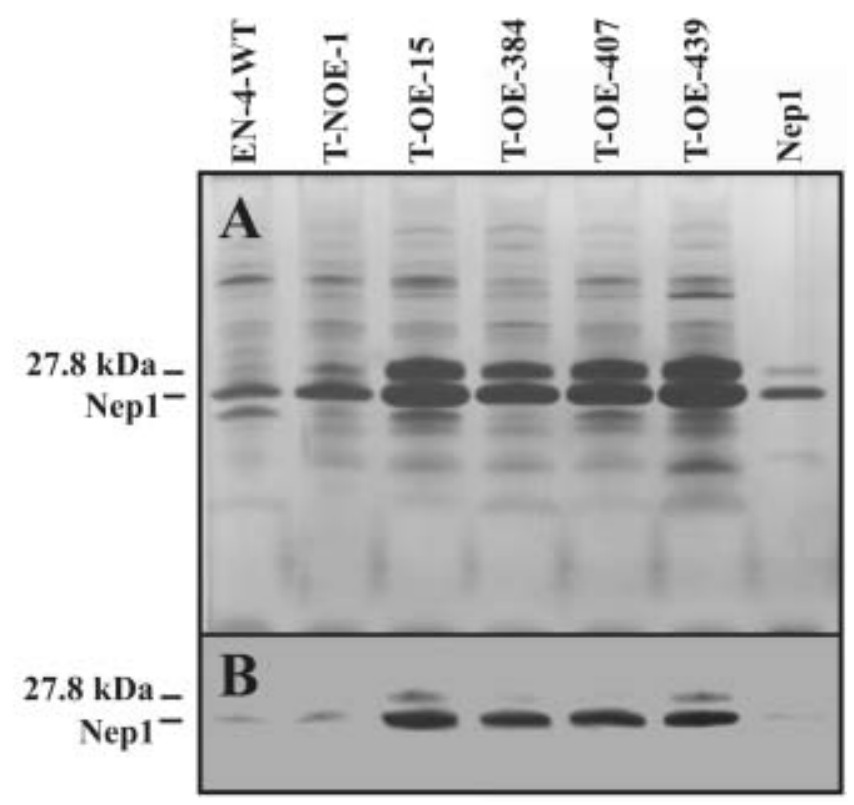

Fig. 4. Culture filtrate protein profiles produced by putative Nep1-overexpressing isolates (T-OE-15, T-OE-384, T-OE-407, and T-OE-439) produced by polyethylene glycol-mediated cotransformation using plasmids pPBFO11-45 and pTHT/Bluescript $\mathrm{SK}^{+}$. Isolates producing wild-type levels of Nep1 (EN-4 wild type and T-NOE-1) are presented for comparisons. The proteins in $5 \mu \mathrm{l}$ of culture filtrate were separated by sodium dodecyl sulfatepolyacrylamide gel electrophoresis and either $\mathbf{A}$, silver stained or $\mathbf{B}$, western blotted. 
at $20 \mathrm{~V}$ on a $1 \%$ Tris-borate-EDTA buffer $(1 \times)$ agarose gel containing ethidium bromide. The gel was then irradiated with UV light for $5 \mathrm{~min}$ to facilitate transfer. The gel was transferred by capillary action to a Zeta-Probe GT Genomic Membrane (Bio-Rad) with $0.4 \mathrm{M}$ sodium hydroxide as the transfer liquid. The blot was neutralized by rinsing in $2 \times$ SSPE $(1 \times$ SSPE is $0.18 \mathrm{M} \mathrm{NaCl}, 10 \mathrm{mM}$ $\mathrm{NaPO}_{4}$, and $1 \mathrm{mM}$ EDTA [pH 7.7]) and baked at $80^{\circ} \mathrm{C}$ for $1 \mathrm{~h}$ in a vacuum oven. The blots were stored dry at room temperature.

RNA was isolated from frozen biomass according to the methods of Yoder (31), except cresol and glass beads were omitted from the protocol. The total RNA (15 $\mu$ g per lane) was separated by electrophoresis in agarose/formaldehyde gels (1.4\% agarose, $6 \%$ formaldehyde, and $1 \times$ MOPS [morpholinepropanesulfonic acid] buffer). Total RNA was mixed with RNA loading mix (Genhunter Corp., Nashville, TN) and heated at $65^{\circ} \mathrm{C}$ for 3 min before being loaded onto the gel. After photographing the ethidium bromidestained gel, the total RNA was transferred by capillary action to Zeta probe GT membranes using $10 \times \mathrm{SSC}(1 \times \mathrm{SSC}$ is $0.15 \mathrm{M}$ $\mathrm{NaCl}$ plus $0.015 \mathrm{M}$ sodium citrate). The blots were rinsed in $1 \times$ $\mathrm{SSC}$, baked at $80^{\circ} \mathrm{C}$ for $30 \mathrm{~min}$, and stored dried at room temperature.

Hybridization conditions. The probe for analyzing northern blots was produced by PCR amplification of the transcribed re-

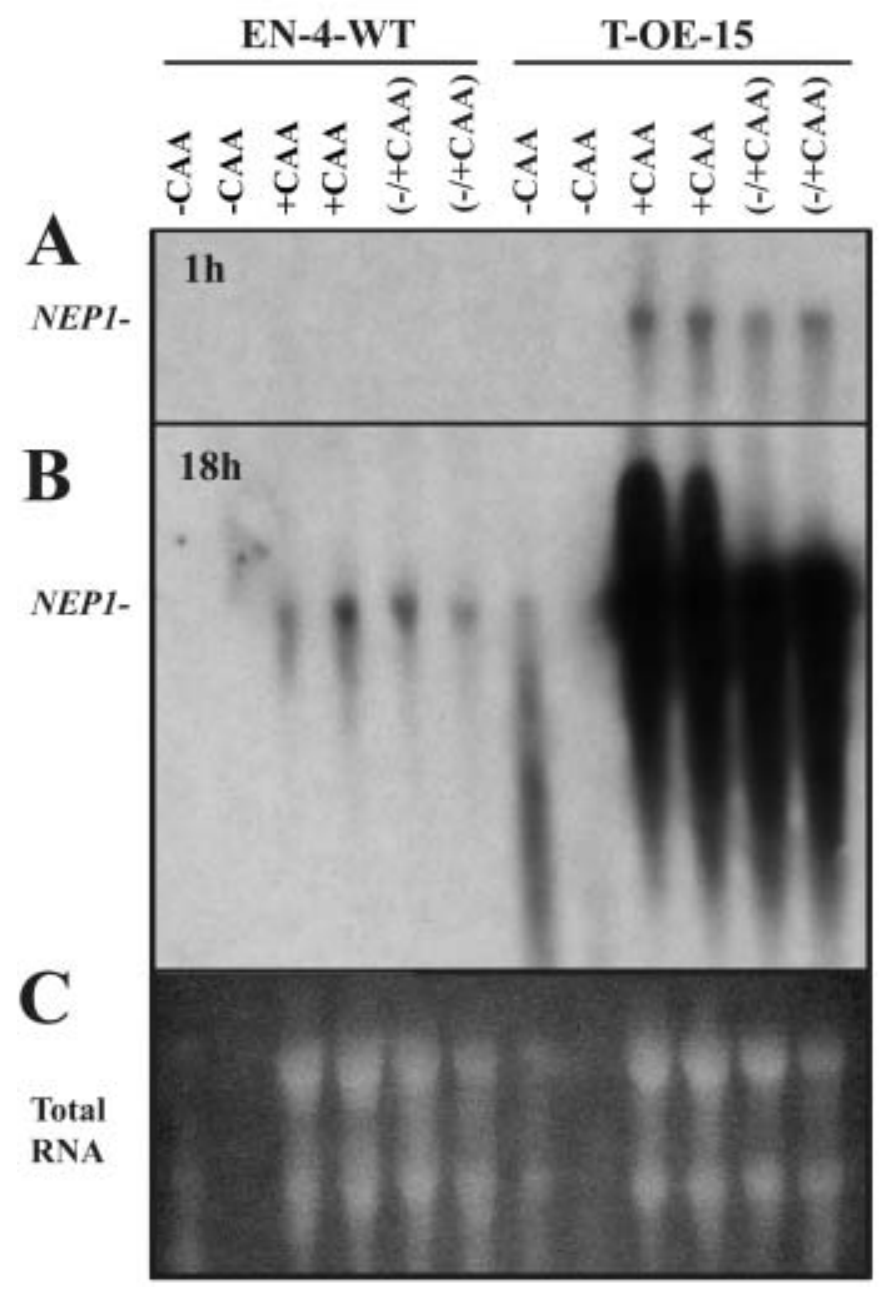

Fig. 5. Production of NEP1 transcript by EN-4 wild type and Nep1-overexpressing T-OE-15 in potato dextrose broth (PDB) or PDB plus $1 \%$ casamino acids (CAA). Total RNA was isolated from biomass grown in PDB (-CAA), PDB plus $1 \%$ CAA (+CAA), or the combination of equivalent biomass from cultures grown in PDB and PDB plus 1\% CAA (-/+ CAA). Twenty micrograms of total RNA was separated on agarose gels blotted, and hybridized to a 842-bp NEP1 probe. The washed blots were exposed to Kodak BioMax MR film for A, $1 \mathrm{~h}$ and $\mathbf{B}, 18 \mathrm{~h}$. C, The ethidium bromide-stained gel is provided for comparisons of total RNA loads. gion (841 bp) of NEP1 from plasmid pFO11-45 using primers p22 and $\mathrm{p} 23$. The probe (381 bp) for analyzing Southern blots was produced by PCR amplification of the $5^{\prime}$ end of NEP1 from pFO11-45 starting at the translation start using primers p22 and p21 (5'-GAGCATATGTCTGACCCTTACTAGTA-3'). The PCR products were separated by electrophoreses and the bands were isolated and purified according to the manufacturers instructions (Geneclean; Bio101, La Jolla, CA). The purified DNA (25 ng in $2 \mu \mathrm{l})$ was labeled with $\left[\alpha^{32} \mathrm{P}\right] \mathrm{dCTP}$ using a random primed DNA labeling kit (F. Hoffmann-La Roche Limited, Indianapolis, IN) and purified with an Edge Gel Filtration Cartridge according to the manufacturers recommended methods. Hybridization and washing were carried out for both northern and Southern analysis with hybridization solution according to the manufacturers instructions (ExpressHybTM; Clontech, Palo Alto, CA). The blots were exposed to Kodak BioMax MR film (Kodak, Rochester, NY) for $1 \mathrm{~h}$ to 3 days prior to developing the film.

Statistical analysis. Data from the pathogenicity bioassays were converted to area under the disease progress curve and analyzed using the SAS general linear models procedure (version 6.04, SAS Institute, Cary, NC). Ethylene production data were transformed using $\log _{10}\left[\left(\mathrm{~nL} \mathrm{C}_{2} \mathrm{H}_{4} / \mathrm{g}\right.\right.$ fresh wt $\left.)+1\right]$ to normalize the data before analysis. All experiments designed for statistical analysis included three replications and were repeated at least twice. Mean comparisons were carried out using LSD $(P \leq 0.05)$.

\section{RESULTS}

Identification and molecular analysis of putative NEP1 disrupted isolates. A total of 203 hygromycin resistant transformants were selected in the NEPI-disruption transformation experiment with plasmid $\mathrm{pPB}-\mathrm{FO} 16-1$. Nep1 production by putative NEPl-disruptants was monitored by Tricine-SDS-PAGE of shake culture filtrates followed by silver staining or western blotting. Ten hygromycin resistant transformants consistently failed to produce Nep1 when grown in CDX plus 1\% CAA liquid shake culture for an efficiency of $4.9 \%$. Putative NEPl-disruptants 415 , 584, 516, and 683 (T-D-415, T-D-584, T-D-516, and T-D-683) were chosen for protein analysis (Fig. 2). Also, transformant 537

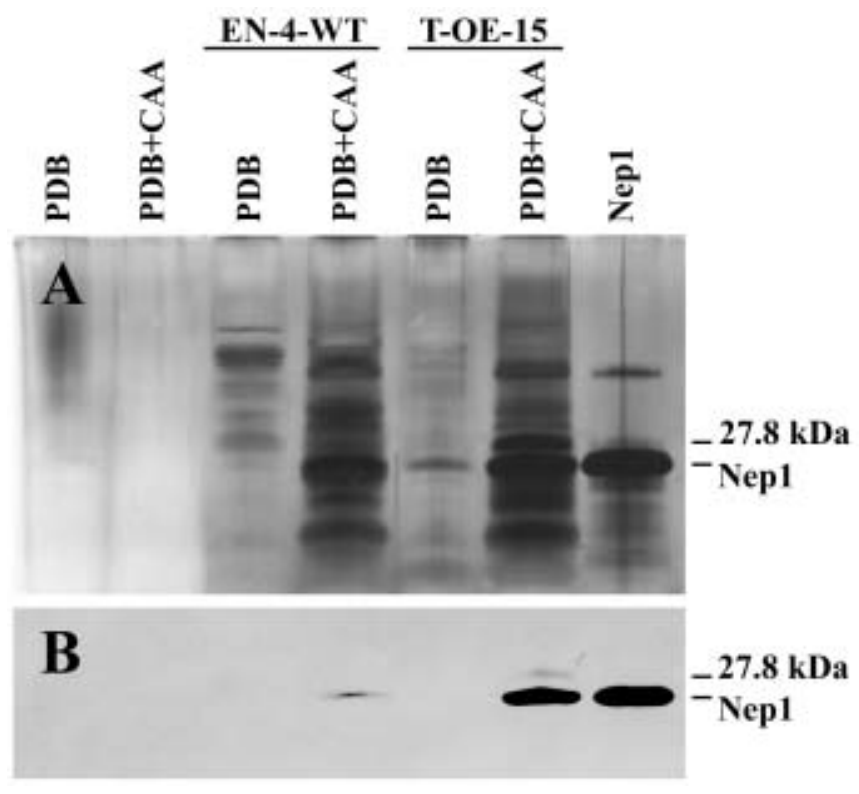

Fig. 6. Production of Nep1 by EN-4 wild type and NEP1-overexpressing TOE-15 in potato dextrose broth (PDB) or PDB plus $1 \%$ casamino acids (CAA). Isolates were grown for 7 days at $25^{\circ} \mathrm{C}$ in liquid shake cultures $(100 \mathrm{rpm})$. The proteins in $5 \mu \mathrm{l}$ of culture filtrate were separated by sodium dodecyl sulfate-polyacrylamide gel electrophoresis and either $\mathbf{A}$, silver stained or $\mathbf{B}$, western blotted. 
(T-ND-537) was chosen for protein analysis from the disruption transformation experiment as a hygromycin resistant transformant that produced wild-type levels of Nep1 (Fig. 2).

The disruption of NEPI was verified by Southern and northern blot analysis. The 381-bp internal NEPI probe hybridized to a single band of approximately $1,800 \mathrm{bp}$ on Southern blots (Fig. 3) of SmaI digests of DNA of isolate EN-4 and T-ND-537, matching the predicted size $(1,801 \mathrm{bp})$ from the wild-type sequence (23). The same probe failed to hybridize to SmaI digests of DNA from transformants T-D-415, T-D-421, T-D-584, T-D-516, and T-D-683 (Fig. 3) as expected, because NEP1 had been replaced by the $\mathrm{Hph}^{\mathrm{R}}$ gene. The 842-bp probe failed to detect transcripts of NEP1 on northern blots of total RNA from T-D-516 and T-D-683 grown under the same conditions, whereas EN-4 wild type had detectable levels of NEPI transcript (data not shown).

Identification and molecular analysis of putative NEP1 overexpressing isolates. In two cotransformation experiments with plasmids pPB-FO11-45 and pTHT/Bluescript $\mathrm{SK}^{+}$, approximately $50 \%$ of the 220 hygromycin resistant transformants were overproducing Nep1 in CDX plus 1\% CAA shake cultures when compared with EN-4 wild type. Among the many isolates putatively overexpressing $N E P 1$, transformants $15,384,407$, and 439 (T-OE-15, T-OE-384, T-OE-407, and T-OE-439) were chosen for protein analysis (Fig. 4). Transformant 1 (T-NOE-1) was also chosen for protein analysis from cotransformation experiments as a hygromycin resistant transformant that produced wild-type levels of Nep1 (Fig. 4). Overexpression of NEP1 enhanced production of both the 24,000-Da Nep1 and a protein of approximately $27,800 \mathrm{Da}$ (Fig. 4). Both peptides cross-react with antisera to Nep1 (4). The concentration of the 27,800-Da protein varies widely between fermentation experiments when using EN-4 wild type and can be difficult to purify away from the 24,000-Da Nep1 (1). It is possible the 27,800-Da protein is the 24,000-Da Nep1 with the leader peptide sequence attached (23) that would add 3,210 Da to Nep1. The high rate of Nep1 production under optimal conditions may overwhelm the normal peptide processing mechanism. These results suggest that both peptides originate from NEPl.

The overexpression of NEP1 after cotransformation of EN-4 with pPB-FO11-45 and pTHT/Bluescript $\mathrm{SK}^{+}$was verified by Southern and northern blot analysis. One to five novel bands with sizes from $3,500 \mathrm{bp}$ to greater than $5,400 \mathrm{bp}$ were identified by the 381-bp NEP1 probe of SmaI-digested DNA from T-OE-2, T-OE15, T-OE-383, T-OE-407, and T-OE-439 (Fig. 3), indicating that multiple integration events occurred in most overexpressing isolates. NEP1 transcript was highly represented on northern blots of total RNA isolated from T-OE-15 grown in PDB plus 1\% CAA compared with northern blots of total RNA from EN-4 wild type (Fig. 5).

Effect of growth media on Nep1 production. Neither T-OE15 nor EN-4 wild type produced observable intact NEP1 transcript or total RNA when the fungi were grown in PDB alone prior to RNA isolation (Fig. 5). Degraded NEPI transcript was observed on northern blots of total RNA isolated from T-OE-15 grown in PDB. Shortening the incubation time to 2, 3, or 4 days did not improve our ability to isolate intact total RNA from EN-4 or T-OE15 grown in PDB (data not shown). NEPl transcript was highly represented on northern blots of total RNA isolated from samples composed of mycelia grown in PDB combined in equal weights with mycelia grown in PDB plus CAA. The degradation of total RNA from cultures grown in PDB occurs prior to the extraction process and is not a function of culture age, which may indicate an excessively fast turnover rate of transcripts.

PDB is a common medium for culturing fungi, including $F$. $o x y$ sporum. The average weight of biomass produced by T-OE- 15 and EN-4 wild type was 0.177 and $0.257 \mathrm{~g}$ dry weight per $50 \mathrm{ml}$, respectively, when grown in PDB compared with 0.427 and $0.463 \mathrm{~g}$ dry weight per $50 \mathrm{ml}$ when grown in PDB plus 1\% CAA. As expected (28), both EN-4 wild type and T-OE-15 produced reduced levels and different patterns of total extracellular protein when grown in PDB compared with growth in PDB plus $1 \%$ CAA (Fig. 6A). The culture conditions have a strong regulatory influence on Nep1 production even when NEPl is placed behind a promoter expected to give constitutive expression. EN-4 wild type or NEP1 overexpressing T-OE-15 do not produce Nep1 when grown in PDB (Fig. 6B). Nep1 production is restored by the addition of $1 \%$ CAA. This effect is a general phenomenon related to growth and extracellular protein production by $F$. oxysporum under limiting conditions and not specific to NEPI.

Altering NEP1 expression does not affect pathogenicity. Ten NEPI disruptants and 10 Nep1 overproducing transformants were evaluated to verify the reproducibility of their morphological and growth characteristics and to determine their pathogenicity to coca (Table 1). NEP1 disruption or overexpression did not affect growth rate, colony morphology, pigmentation, spore type, or spore number produced by the transformants, which would have suggested a possible function for Nep1 (data not shown). All the selected transformants were pathogenic to coca in root dip bioassays (Table 1). Kill of coca by NEP1-disrupted or overexpressing transformants in root dip bioassays was nearly complete between 4 and 12 weeks after treatment following patterns similar to results with wild-type strains. Differences in rate of coca kill between the

TABLE 1. Bioassay of disease area under disease progress curve (AUDPC) caused by wild-type NEP1-disrupted and NEP1-overexpressing transformants of Fusarium oxysporum f. sp. erythroxyli isolate EN-4 on Erythroxylum coca var. $\operatorname{coca}^{\mathrm{x}}$

\begin{tabular}{ll}
\hline Isolate & AUDPC \\
\hline T-OE-439 & $144.7 \mathrm{a}$ \\
T-NOE-1 & $144.7 \mathrm{a}$ \\
T-D-604 & $133.0 \mathrm{ab}$ \\
T-OE-411 & $133.0 \mathrm{ab}$ \\
T-NOE-16 & $133.0 \mathrm{ab}$ \\
T-D-421 & $131.7 \mathrm{ab}$ \\
T-D-516 & $130.7 \mathrm{a}-\mathrm{c}$ \\
T-D-683 & $123.7 \mathrm{a}-\mathrm{d}$ \\
T-OE-332 & $121.3 \mathrm{a}-\mathrm{d}$ \\
T-D-677 & $119.0 \mathrm{a}-\mathrm{d}$ \\
T-D-602 & $119.0 \mathrm{a}-\mathrm{d}$ \\
T-OE-384 & $119.0 \mathrm{a}-\mathrm{d}$ \\
T-D-670 & $117.8 \mathrm{a}-\mathrm{d}$ \\
T-D-651 & $115.5 \mathrm{a}-\mathrm{d}$ \\
T-ND-591 & $114.2 \mathrm{a}-\mathrm{d}$ \\
T-OE-407 & $113.8 \mathrm{a}-\mathrm{d}$ \\
T-OE-4 & $111.8 \mathrm{a}-\mathrm{d}$ \\
T-OE-370 & $107.3 \mathrm{~b}-\mathrm{e}$ \\
T-D-584 & $106.4 \mathrm{~b}-\mathrm{e}$ \\
T-ND-537 & $102.7 \mathrm{~b}-\mathrm{e}$ \\
T-OE-479 & $98.0 \mathrm{c}-\mathrm{e}$ \\
T-D-415 & $96.8 \mathrm{de}$ \\
T-OE-15 & $95.7 \mathrm{de}$ \\
EN-4-WT & $94.5 \mathrm{de}$ \\
T-OE-2 & $75.8 \mathrm{e}$ \\
T-OE-411 (HK) & $0 \mathrm{f}$ \\
T-D-415 (HK) & $0 \mathrm{f}$ \\
EN-4-WT (HK) & $0 \mathrm{f}$ \\
\hline & \\
\hline
\end{tabular}

$x$ The pathogenicity of EN-4 wild type and selected EN-4 transformants with altered NEP1 expression was determined using a root-dip assay (23).

${ }^{y}$ Twenty-five isolates were evaluated including $10 \mathrm{NEPl}$-disrupted transformants (D), 10 NEPl-overexpressing transformants (OE), 2 hygromycin resistant transformants from the disruption experiments with normal Nep1 production (ND), 2 hygromycin resistant transformants from the overexpression experiments with normal Nep1 production (NOE) and EN-4 wild type (WT). Autoclaved inoculum (HK) of both EN-4 wild type and several EN-4 transformants were included as controls.

${ }^{\mathrm{z}}$ Isolates were rated based on the number of defoliated seedlings per pot with each pot having a maximum score of 4 . The data were converted to AUDPC and analyzed using the SAS general linear models procedure (version 6.04, SAS Institute, Cary, NC). Means followed by a common letter are not significantly different based on $\operatorname{LSD}(P \leq 0.05)$. 
selected transformants were minor and not grouped according to NEPI alteration (disrupted or overexpressing).

Symptoms of disease development in plants treated with NEP1disrupted transformants included chlorosis and abscission of leaves followed by death. Although many aspects of the infection process are bypassed in the root-dip assay, Fusarium wilt in coca, as demonstrated by the root dip assay, is not dependent upon NEP1 expression.

Transformants were stable through infection process. $F$. $o x y$ sporum was consistently observed growing from the cut ends of stem sections of symptomatic coca seedlings plated on Komada's medium. At least six isolations were made from seedlings treated with each of $25 \mathrm{~F}$. oxysporum isolates, which included $10 \mathrm{NEPl-}$

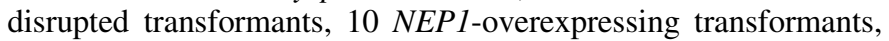
4 hygromycin resistant transformants with normal Nep1 production, and EN-4 wild type. Without exception, isolates recovered from seedlings treated with NEPl-disrupted transformants failed to produce Nep1 in liquid culture (data not shown). Similarly, iso-

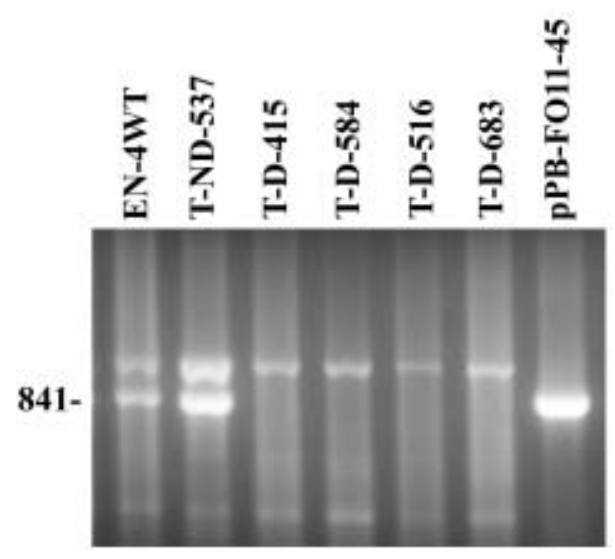

Fig. 7. Verification of NEP1 distruption in Fusarium oxysporum f. sp. erythroxyli isolates recovered from symptomatic coca seedlings inoculated with NEP1-disrupted isolates T-D-415, T-D-584, T-D-516, and T-D-683. Primers p22 and p23, both residing within $N E P 1$, were used for polymerase chain reaction amplification using DNA from the recovered isolates. DNA from EN-4 wild type and T-ND-537, which express native NEP1 and were recovered from symptomatic coca seedlings, were included for comparisons.

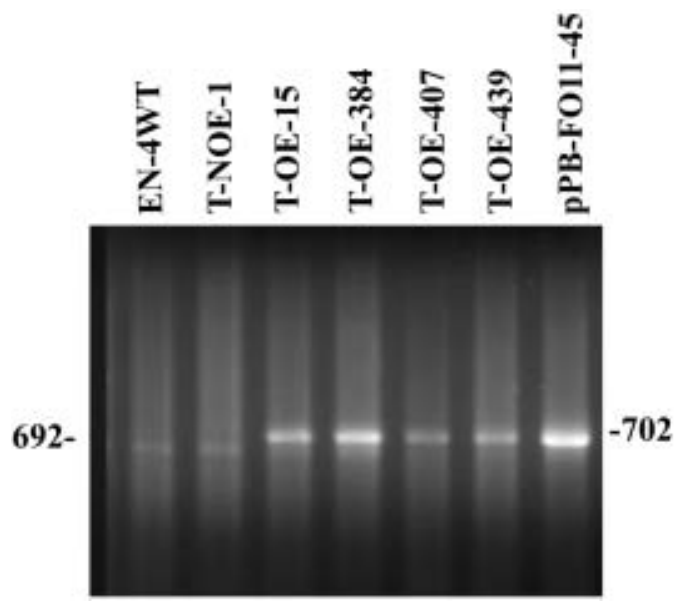

Fig. 8. Verification that Fusarium oxysporum f. sp. erythroxyli isolates recovered from symptomatic coca seedlings inoculated with $N E P 1$-overexpressing isolates T-OE-15, T-OE-384, T-OE-407, and T-OE-439 continue to carry transformed copies of NEP1. Primers p39, located in the trpC promoter, and $\mathrm{p} 29$, located $3^{\prime}$ to the transcription start site of $N E P 1$, were used for polymerase chain reaction amplification of DNA from recovered isolates. DNA from EN-4 wild type and isolate 1, which carry only the native $N E P 1$ and were recovered from symptomatic coca seedlings, were included for comparisons. lates recovered from seedlings treated with $N E P 1$-overexpressing transformants all overproduced Nep1 in liquid culture when compared with wild-type Nep1 production levels (data not shown).

A subset of isolates recovered from infected plants were analyzed by PCR to verify their identity at the molecular level. DNA from isolates recovered from symptomatic coca plants inoculated with T-D-421, T-D-516, T-D-584, and T-D-683 lacked the 840-bp band when analyzed by PCR (Fig. 7), similar to the results obtained with the original strains (data not shown), showing that they lacked the wild-type NEP1. After re-isolating T-ND-537 and EN-4 wild type from infected tissue, the 841-bp band could be PCR amplified from the genomic DNA. PCR amplification of DNA from isolates recovered from symptomatic coca plants inoculated with T-OE-15, T-OE-384, T-OE-407, and T-OE-439 had a 690-bp band (Fig. 8), similar to results obtained with the original isolates (data not shown), verifying they still carried extra copies of NEPI. The 690-bp band was not present after PCR amplification of DNA from symptomatic plants inoculated with EN-4 wild type or TNOE-1. The alterations in NEPI expression remained stable during the 10 to 12 weeks required to complete the pathogenicity evaluations.

Nep1 cannot be detected in coca infected with NEP1-overexpressing isolates. Attempts at detecting Nep1 in coca stems infected with NEP1-overexpressing transformants were unsuccessful. Nep1 was not observed when protein extracts from infected coca stems were evaluated by Tricine-SDS-PAGE and western analysis (data not shown). The pathogenicity bioassay for $\mathrm{Fu}-$ sarium wilt of coca is relatively slow, taking 10 to 12 weeks, and the woody stems are not ideally suited to protein extraction. The results were similar to those of an earlier study using extracts from coca stems infected with EN-4 wild type (4). This suggests that either our detection techniques were insensitive or, more probably, that Nep1 production and processing is limited in plant tissue. Unlike gene disruption where we know the effect of the gene alteration in plant tissue (i.e., Nep1 is not produced), it is difficult to prove or disprove overproduction of Nep1 in plant tissue simply by the lack of detection. No attempts were made to detect $N E P 1$ transcript in infected plant tissue because it could not conclusively prove Nep1 production.

Comparisons between Nep1 production levels and biological activity of transformants and EN-4 wild type. The NEP1overexpressing T-OE-15 produced 64 to 128 times more $24-\mathrm{kDa}$ Nep1 in 7 day shake cultures than did EN-4 wild type based on dilution gel staining assays (Fig. 9). This does not include the 27,800-Da protein, which can accumulate in culture filtrates of TOE-15 to levels 8 to 16 times greater than the level of the 24,000-Da Nep1 in EN-4 wild type. Culture filtrates from NEP1-overexpress-

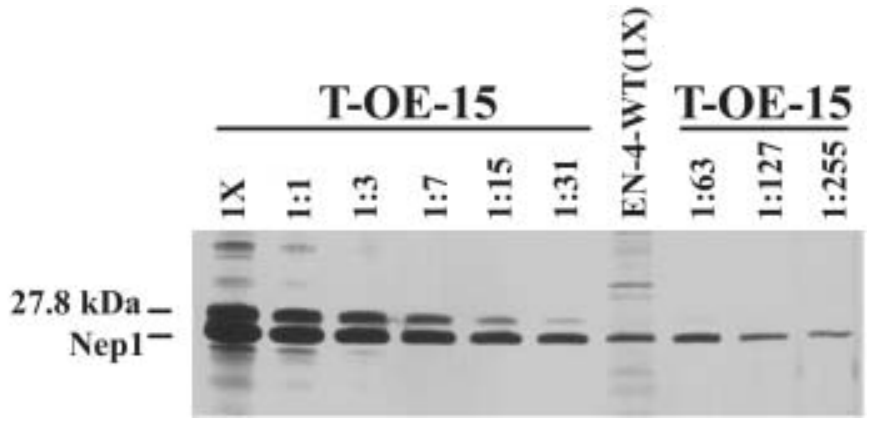

Fig. 9. Comparison of Nep1 production between NEP1-overexpressing isolate T-OE-15 and EN-4 wild type. Liquid cultures of EN-4 wild type and isolate 15 were grown in Czapek-Dox broth plus $1 \%$ casamino acids for 5 days at $25^{\circ} \mathrm{C}$ shaking at $100 \mathrm{rpm}$. Culture filtrates from isolate 15 were diluted (1:1 to $1: 255)$ with distilled $\mathrm{H}_{2} \mathrm{O}$ for comparison to undiluted EN-4 wild-type culture filtrate. The proteins in diluted and undiluted culture filtrates $(10 \mu \mathrm{l})$ were separated by Tricine-sodium dodecyl sulfate-polyacrylamide gel electrophoresis and silver stained. 
ing transformants (Fig. 3) elicited on average 2.9 times more ethylene from coca leaves than did EN-4 wild type (Fig. 10) in detached leaf bioassays. Isolates expressing NEPl at wild-type levels (Fig. 2) elicited on average 3.7 times more ethylene from coca leaves than did NEPl-disrupted transformants (Fig. 10). $N E P 1$-disrupted strains continued to elicit significantly greater ethylene from coca leaves than did the media control. The response of coca to Nep1 is complex, involving aspects of leaf age, leaf size, protein uptake, protein transport, and other factors leading to signal transduction resulting in ethylene production and other responses such as necrosis. As a result, the ethylene response is not linear with Nep1 concentration (1) and demonstrates considerable variability between leaf samples.

EN-4 wild type and T-OE-15 produced 17.9 and $22.4 \mathrm{~g}$ dry weight of biomass, respectively, when grown for 10 days in CDX plus $1 \%$ CAA in 10-liter carboys. Spore production was similar for both isolates over the length of the experiments (data not shown). The NEP1-overexpressing T-OE-15 rapidly accumulated Nep1 in the liquid medium when grown in 10-liter carboys (Fig. 11 ). Both the 27.8- and 24-kDa bands accumulated in the culture medium, with the $24-\mathrm{kDa}$ band most highly represented. The culture medium for T-OE-15 had $76 \mathrm{mg}$ of total protein per liter after only 3 days of incubation, most of which was Nep1. T-OE-15 produced $264 \mathrm{mg}$ of total protein per liter of medium after 9 days of incubation. EN-4 wild type slowly accumulated extracellular protein and Nep1, but produced only $17.5 \mathrm{mg}$ of total protein per liter of medium after 10 days of incubation.

\section{DISCUSSION}

The expression of many $F$. oxysporum genes has been detected in infected plant tissue based on presence of enzyme activities $(8,29)$ or transcripts $(7,9,11,25)$. A precursory look suggests Nep1 is not produced in infected tissue even by the NEP1-overexpressing isolates. Nep1 production in liquid culture is dependent on the availability of a nutrient rich medium (4), a condition not found during infection by $F$. oxysporum, except possibly in the late stages of disease development (5). The xylem, where primary growth and development of $F$. oxysporum occurs in vascular wilts, is nutritionally dilute (18), possibly limiting Nep1 production as well as production of many other intercellular and extracellular proteins. It remains unclear if Nep1 is important for fungal competition in the soil or for the natural infection process with intact roots.

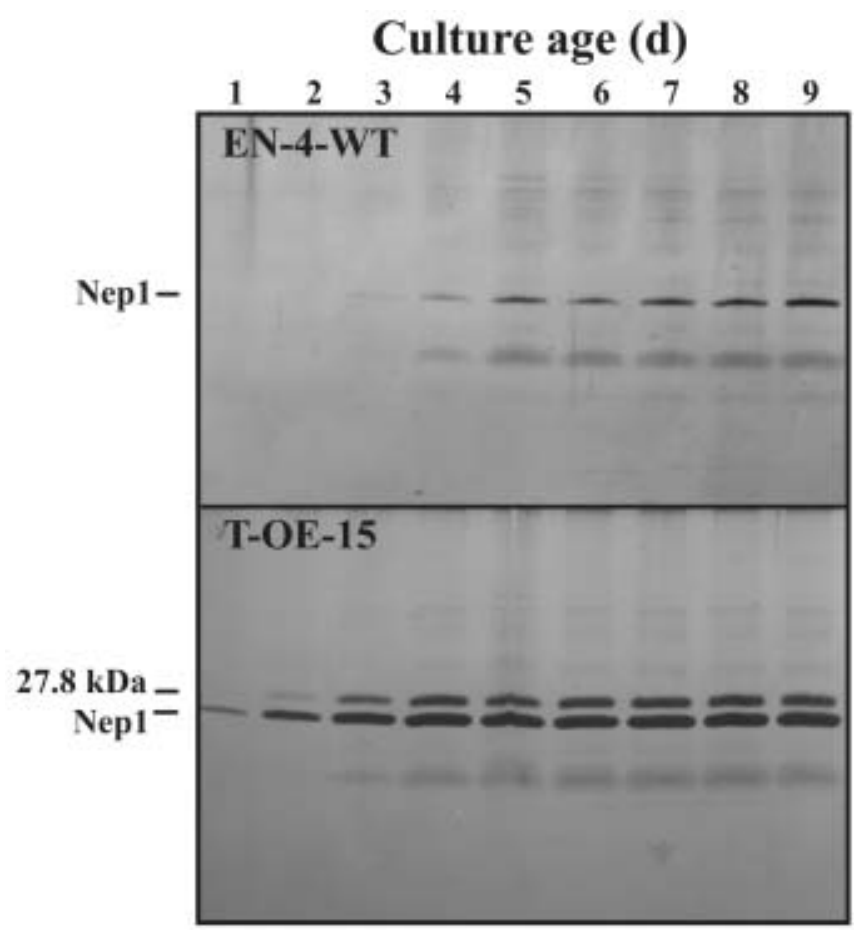

Fig. 11. Production of Nep1 by EN-4 wild type and NEP1-overexpressing isolate T-OE-15 during large-scale fermentation. Large-scale fermentation was carried out in 10-liter carboys filled with 6 liters of Czapek-Dox broth plus $1 \%$ casamino acids maintained at room temperature (approximately $23^{\circ} \mathrm{C}$ ) for 9 days. Carboys were inoculated with $20 \mathrm{ml}$ of 2-day cultures of EN-4 wild type or T-OE-15. The carboys were sparged with filtered air (approximately 100 liters per h). Proteins in $5 \mu \mathrm{l}$ of daily samples were separated by Tricine-sodium dodecyl sulfate-polyacrylamide gel electrophoresis and then silver stained for comparisons.

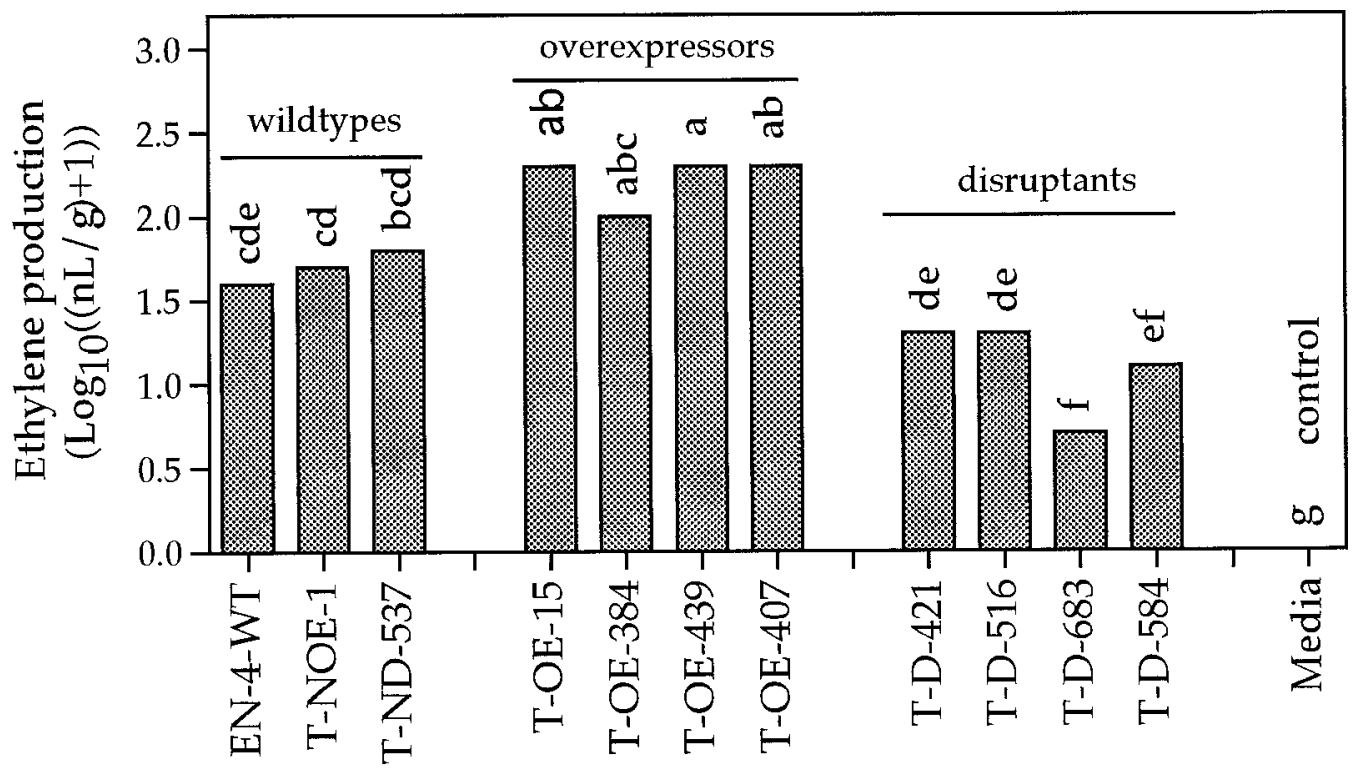

\section{Isolate}

Fig. 10. Ethylene production by detached coca leaves after treatment with culture filtrates from Fusarium oxysporum f. sp. erythroxyli isolates expressing wildtype NEP1 (En-4 wild type, and T-NOE-1 and T-ND-537), disrupted for NEP1 (T-D-421, T-D-516, T-D-683, and T-D-584), or overexpressing NEP1 (T-OE-15, T-OE-384, T-OE-439, and T-OE-407). Culture filtrate $(5 \mu \mathrm{l})$ was applied as a hanging drop to the leaf petiole. Ethylene measurements were converted to Log 10 $[(\mathrm{nL} / \mathrm{g}$ fresh weight $)+1]$ values before analysis. Means sharing the same letter are not significantly different according to LSD $(P \leq 0.05)$. 
The regulation of gene expression by pathogens during pathogenesis is necessarily complex. Elicitin INF1, an elicitor from Phytophthora infestans, was at least partially down-regulated during infection of potato (15). Two xylanases were differentially expressed during infection of tomato by $F$. oxysporum f. sp. lycopersici, with $x y l 3$ being expressed throughout the disease cycle and $x y l 2$ being expressed only during the final stages of disease (25). In direct contrast to the observed regulation of NEP1, the Avr9 gene of Cladosporium fulvum is strongly down-regulated in rich media, induced by nitrogen stress, and is expressed in plant tissue (24). It is possible that regulatory elements in the 505 bp of Nep1 sequence upstream of the translational start included in the construct pPB-FO11-45 are controlling Nep1 production in the NEPIoverexpressing isolates. It is unclear if the $N E P 1$-overexpression observed in liquid culture is due to regulation of the introduced gene copies by the TrpC promoter or simply due to the presence of multiple copies of the gene in the NEPl-overexpressing isolates. Regardless, Nep1 production by the NEP1-overexpressing isolates seems to be under many of the same constraints as wildtype production because transcript production is affected by the addition of CAA to the culture medium. Regulation of Nep1 production may be occurring at many points including transcription (10), translation or posttranslation involving mRNA (27), or protein stability (21). The ultimate effect is that our construct in multiple NEPl-overexpressing transformants does not influence pathogenicity of $F$. oxysporum f. sp. erythroxyli in the host plant coca. However, the $F$. oxysporum transformants may be useful in exploring the regulatory processes in the fungus.

The function of Nep1 in the physiology of F. oxysporum is unknown. The loss of the ability to produce Nep1 did not significantly affect the growth of $F$. oxysporum isolate EN-4 during saprophytic growth in liquid culture or during the disease process. Likewise, altering expression of NEP1 did not affect plant pathogenicity. Pathogenicity was similarly unaffected in other hostpathogen interactions in which gene disruption of potential pathogenicity factors was carried out $(7,9)$. Genes related to NEPI are found in widely divergent microbes, many of which are plant pathogens. It is unknown if they share similar regulatory controls, and their functions in the physiology of the respective microbes remains unclear.

Nep1 may prove useful as an inexpensive, fermentable, broadspectrum contact bioherbicide. It has been demonstrated that partially purified Nep1 protein preparations are biologically active, acting as a contact herbicide when applied to spotted knapweed (3), and the damaging effects of Nep1 on other broadleaf weeds has also been demonstrated (13). It is clear that the NEP1 overexpression strain is stably transformed and well suited for this task. The transformant maintained its ability to overproduce Nep1 during 12 weeks of pathogenicity testing without antibiotic selective pressure. Overexpression of NEPl resulted in enhanced production of Nep1 in liquid culture. Nep1 was correctly processed and excreted from the cell. Nep1 accumulated rapidly during large-scale fermentation of NEPl-overexpressing T-OE-15 with $29 \%$ being produced within 3 days. NEPI-overexpressing T-OE15 produced 15.1 times as much total protein in large-scale fermentation and 64 to 128 times as much Nep1 in shake culture compared with the wild type. In an effort to improve production, Margolles-Clark et al. (20) expressed Trichoderma harzianum endochitinase in $T$. reesei resulting in a 20 -fold increase. The $264 \mathrm{mg}$ of total protein per liter of media produced by T-OE-15 after 9 days of incubation in large-scale fermentation, although significant compared with EN-4 wild-type production, can likely be improved. The conditions used for large-scale fermentation of EN-4 and T-OE-15 were standard laboratory conditions and had not been optimized for Nep1 production. Under optimal conditions, cultures of mutant strains of $T$. reese $i$ can produce $40 \mathrm{~g}$ of protein per liter (19). Changes in the culture medium and culture conditions are likely to greatly improve the efficiency of Nep1 production. Nep1 production may be ideally suited for a continuous flow culture system, because Nep1 is an extracellular protein. Processing Nep1 containing culture filtrates prior to use as a herbicide may be as simple as concentrating the protein and removing large and small contaminants by ultrafiltration techniques (3). A NEPl-overexpressing transformant would greatly simplify this process by diluting out contaminants while greatly increasing protein yield.

\section{LITERATURE CITED}

1. Bailey, B. A. 1995. Purification of a protein from culture filtrates of Fusarium oxysporum that induces ethylene and necrosis in leaves of Erythroxylum coca. Phytopathology 85:1250-1255.

2. Bailey, B. A., Apel-Birkhold, P. C., Akingbe, O. O., Ryan, J. L., O'Neill, N. R., and Anderson, J. D. 2000. Nep1 protein from Fusarium oxysporum enhances biological control of opium poppy by Pleospora papaveracea. Phytopathology 90:812-818.

3. Bailey, B. A., Collins, R., and Anderson, J. D. 2000. Factors influencing the herbicidal activity of Nep1, a fungal protein that induces the hypersensitive response in Centaurea maculosa. Weed Sci. 48:776-785.

4. Bailey, B. A., Jennings, J. C., and Anderson, J. D. 1997. The 24-kDa protein from Fusarium oxysporum $f$. sp. erythroxyli: Occurrence in related fungi and the effect of growth medium on its production. Can. J. Microbiol. 43:45-55.

5. Beckman, C. H. 1987. The Nature of Wilt Diseases of Plants. The American Phytopathological Society, St. Paul, MN.

6. Cullen, D., Leong, S. A., Wilson, L. J., and Henner, D. J. 1987. Transformation of Aspergillus nidulans with the hygromycin-resistance gene, hph. Gene 57:21-26.

7. Di Pietro, A., Huertas-Gonzalez, M. D., Gutierrez-Corona, J. F., Martinez-Cadena, G., Meglecz, E., and Roncero, M. I. G. 2001. Molecular characterization of subtilase from the vascular wilt fungus Fusarium oxysporum. Mol. Plant-Microbe Interact. 14:653-662.

8. Di Pietro, A., and Roncero, M. I. G. 1996. Endopolygalacturonase from Fusarium oxysporum f. sp. lycopersici: Purification, characterization, and production during infection of tomato plants. Phytopathology 86: 1324-1330.

9. Garcia-Maceira, F. I., De Pietro, A., and Roncero, I. G. 2000. Cloning and disruption of pgx4 encoding an in planta expressed exopolydalactouronase from Fusarium oxysporum. Mol. Plant-Microbe Interact. 13:359-365.

10. Gasch, A. P., Spellman, P. T., Kao, C. M., Carmel-Harel, O., Eisen, M. B., Storz, G., Botstein, D., and Brown, P. O. 2000. Genomic expression programs in response of yeast cells to environmental changes. Mol. Biol. Cell. 11:4241-4257.

11. Huertas-Gonzalez, M. D., Ruiz-Roldan, M. C., Maceira, F. I. G., Roncero, M. I. G., and Di Pietro, A. 1999. Cloning and characterization of pl1, encoding an in planta-secreted pectate lyase of Fusarium oxysporum. Curr. Genet. 35:36-40.

12. Inoue, I., Ohara, T., Namiki, F., and Tsuge, T. 2001. Isolation of pathogenicity mutants of Fusarium oxysporum f. sp. melonis by insertional mutagenesis. J. Gen. Plant Pathol. 67:191-199.

13. Jennings, J. C., Birkhold, P. C., Bailey, B. A., and Anderson, J. D. 2000. Induction of ethylene biosynthesis and necrosis in weed leaves by a Fusarium oxysporum protein. Weed Sci. 48:7-14.

14. Jennings, J. C., Birkhold, P. C., Baker, C. J., Anderson, J. D., and Bailey, B. A. 2001. Physiological responses of tobacco to the $24 \mathrm{kDa}$ elicitor from Fusarium oxysporum. Plant Sci. 161:891-899.

15. Kamoun, S., van West, Pieter, de Jong, A. J., de Groot, K. E., Vleeshouwers, V. G. A. A., and Govers, F. 1997. A gene encoding a protein elicitor of Phytophthora infestans is down-regulated during infection of potato. Mol. Plant-Microbe Interact. 10:13-20.

16. Kistler, H. C., and Benny, U. K. 1988. Genetic transformation of the fungal plant pathogen, Fusarium oxysporum. Curr. Genet. 13:145-149.

17. Komada, H. 1975. Development of a selective medium for quantitative isolation of Fusarium oxysporum from natural soil. Rev. Plant Prot. Res. 8:114-124.

18. MacHardy, W. E., and Beckman, C. H. 1981. Vascular wilt fusaria: Infection and pathogenesis. Pages 365-390 in: Fusarium: Diseases, Biology, and Taxonomy. P. E. Nelson, T. A. Toussoun, and R. J. Cook, eds. Pennsylvania State University Press, University Park.

19. Mantyla, A., Paloheimo, M., and Suominen, P. 1998. Industrial mutants and recombinant strains of Trichoderma reesei. Pages 289-309 in: Trichoderma \& Gliocladium, Vol. 2. Enzymes, Biological Control and Commercial Applications. G. E. Harman and C. P. Kubicek, eds. Taylor \& Francis, Ltd., London.

20. Margolles-Clark, E., Hayes, C. K., Harman, G. E., and Penttila, M. 1996. 
Improved production of Trichoderma harzianum endochitinase by expression in Trichoderma reesei. Appl. Environ. Microbiol. 62:21452151.

21. McIntyre, M., Berry, D. R., and McNeil, B. 2000. Role of proteases in autolysis of Penicillium chrysogenum chemostat cultures in response to nutrient depletion. Appl. Microbiol. Biotechnol. 53:235-242.

22. Nelson, A. J., Apel-Birkhold, P. C., and Bailey, B. A. 1998. Sequence announcements: GenBank Accession No. AF036580. Plant Mol. Biol. 38:911-912.

23. Nelson, A. J., Elias, K. S., Arevalo, E. G., Darlington, L. C., and Bailey, B. A. 1997. Genetic characterization by RAPD analysis of isolates of $F u$ sarium oxysporum f. sp. erythroxyli associated with an emerging epidemic in Peru. Phytopathology 87:1220-1225.

24. Perez-Garcia, A., Snoeijers, S. S., Joosten, M. H. A., Goosen, T., and De Wit, P. J. G. M. 2001. Expression of the avirulence gene Avr9 of the fungal tomato pathogen Cladosporium fulvum is regulated by global nitrogen response factor NRF1. Mol. Plant-Microbe Interact. 14:316325.

25. Ruiz-Roldan, M. C., De Pietro, A., Huertas-Gonzalez, M. D., and
Roncero, M. I. G. 1999. Two xylanase genes of the vascular wilt pathogen Fusarium oxysporum are differentially expressed during infection of tomato plants. Mol. Gen. Genet. 261:530-536.

26. Schagger, H., and Jagow, G. 1987. Tricine-sodium dodecyl sulfate-polyacrylamide gel electrophoresis for the separation of proteins in the range from 1 to $100 \mathrm{kDa}$. Anal. Biochem. 166:368-379.

27. Schroder, M., Chang, J. S., and Kaufman, R. J. 2000. The unfolded protein response represses nitrogen-starvation induced developmental differentiation in yeast. Genes Dev. 14:2962-2975.

28. Sutherland, M. L., and Pegg, G. F. 1992. The basis of host recognition in Fusarium oxysporum f. sp. lycopersici. Physiol. Mol. Plant Pathol. 40:423-436.

29. Urbanek, H., and Yirdaw, G. 1978. Acid proteases produced by $F u$ sarium species in cultures and in infected seedlings. Physiol. Plant Pathol. 13:81-87.

30. Wray, W., Boulikas, T., Wray, V. P., and Hancock, R. 1981. Silver staining of proteins in polyacrylamide gels. Anal. Biochem. 118:197-203.

31. Yoder, O. C. 1988. Cochliobolus heterostrophus. Cause of southern corn leaf blight. Adv. Plant Pathol. 6:93-112. 